\title{
MODEL KEPEMIMPINAN DI UNIVERSITAS SULAWESI BARAT
}

\author{
Moh. Syarif'
}

\begin{abstract}
1 Universitas Terbuka Tangerang Selatan, Indonesia msyarif.ut@gmail.com

Submitted: 18 October 2021

Revised: 1 December 2021

Accepted: 5 December 2021

This study aims to analyze the leadership model of the Head of Academic and General Bureau of the University of West Sulawesi using the approach of personal characteristics theory of leadership according to Hersey and Blanchard. There are four dimensions of personal characteristics of leaders that form the basis of leadership evaluation in this research including attention management, meaning management, trust management, and self-management. The research approach used is qualitative with case study type. The research data was obtained through direct observation and in-depth interviews of informants. The research data is based on qualitative data processing principles using interactive data analysis models according to Miles and Huberman. The results showed that the personal characteristics of the head of the Academic and General Bureau of the University of West Sulawesi based on attention management characteristics and self-management characteristics have been running to the maximum. But in the characteristics of meaning management has not run to the maximum due to the ability of leaders in applying their creativity to employees or staff is considered not to run optimally such as trying to provide some supporting activities to employees to improve their abilities in each field. Likewise, the characteristics of trust management have not been carried out optimally due to the lack of maximum application of consistency and timeliness in carrying out and carrying out their duties and responsibilities.
\end{abstract}

Keywords: leadership; characteristics; personal; attention; trust

\begin{abstract}
ABSTRAK
Penelitian ini bertujuan untuk menganalisis model kepemimpinan Kepala Biro Akademik dan Umum Universitas Sulawesi Barat dengan menggunakan pendekatan teori karakteristik pribadi kepemimpinan menurut Hersey dan Blanchard. Terdapat empat dimensi karakteristik pribadi pemimpin yang menjadi dasar evaluasi kepemimpinan dalam penelitian ini meliputi pengelolaan perhatian, pengelolaan makna, pengelolaan kepercayaan, dan pengelolaan diri. Pendekatan penelitian yang digunakan adalah kualitatif dengan tipe studi kasus. Data penelitian diperoleh melalui observasi langsung dan wawancara mendalam terhadap informan. Data penelitian dianailis berdasarkan prinsip pengolahan data kualitatif menggunakan model analisis data interaktif menurut Miles dan Huberman. Hasil penelitian menunjukkan bahwa karakteristik pribadi kepemimpinan Kepala Biro Akademik dan Umum Universitas Sulawesi Barat berdasarkan karakteristik pengelolaan perhatian dan karakteristik pengelolaan diri telah berjalan dengan maksimal. Tetapi pada karakteristik pengelolaan makna belum berjalan dengan maksimal disebabkan oleh kemampuan pemimpin dalam mengaplikasikan kreativitasnya kepada para pegawai atau stafnya dianggap belum berjalan dengan optimal seperti berupaya untuk menyediakan beberapa kegiatan-kegiatan pendukung kepada para pegawai untuk meningkatkan kemampuan mereka di setiap bidang. Demikian juga, pada karakteristik pengelolaan kepercayaan belum terlaksana secara optimal disebabkan oleh belum maksimalnya penerapan konsistensi dan ketepatan waktu dalam menjalankan serta melaksanakan tugas dan tanggung jawabnya.
\end{abstract}

Kata Kunci: kepemimpinan; karakteristik; pribadi; perhatian; kepercayaan 


\section{PENDAHULUAN}

Kepemimpinan merupakan aspek penting dan utama dalam penyelenggaraan roda organisasi. Sebagai salah satu unsur utama dari beberapa aspek dari fungsi-fungsi manajemen, kepemimpinan memegang peran strategis dari seluruh fungsi manajemen yang ada. Pemimpin sebagai penggerak didalam organisasi menggerakkan segenap unsur yang ada, dan unsur yang terpenting adalah sumber daya manusia organisasi. Pola hubungan pemimpin dan bawahan dalam organisasi yang terjadi dapat menyebabkan pegawai merasa senang atau tidak senang bekerja dalam sebuah organisasi.

Kepemimpinan (Leadership) adalah peroses mempengaruhi atau memberi contoh kepada pengikut-pengikutnya melalui peroses komunikasi dalam upaya mencapai tujuan organisasi. Kepemimpinan yang dapat dikatakan sebagai cara dari seorang pemimpin dalam mempengaruhi, mengarahkan, mendorong dan mengatur seluruh unsur-unsur didalam kelompok atau organisasinya untuk mencapai suatu tujuan organisasi yang diinginkan sehingga menghasilkan kinerja pegawai yang maksimal. Dengan meningkatnya kinerja pegawai berarti tercapainya hasil kerja seorang atau pegawai dalam mewujudkan tujuan organisasi.

Kepemimpinan dipandang sangat penting karena dua hal, pertama, adanya kenyataan bahwa penggantian pemimpin seringkali mengubah kinerja suatu unit, instansi atau organisasi; kedua, hasil penelitian yang menunjukkan bahwa salah satu faktor internal yang mempengaruhi keberhasilan organisasi adalah kepemimpinan, mencakup proses kepemimpinan pada setiap jenjang organisasi, kompetensi dan tindakan pemimpin yang bersangkutan (Yukl, 1998:252).

Hasil studi awal pada obyek penelitian yang menelaah kepemimpinan Kepala Biro Akademik dan Umum di Universitas Sulawesi Barat Kabupaten Majene Provinsi Sulawesi Barat yang mengkaitkan hubungannya dengan kinerja pegawai yang dipimpinnya. Dimana pada kondisi kinerja pegawai pada instansi tersebut masih menunjukkan belum optimal seperti adanya beberapa tugas yang diemban oleh pegawai tidak terlaksana atau tertunda penyelesaiannya sehingga menimbulkan komplain dari pihak terlayani, indikasi ini nampak pada pada adanya aduan tertulis maupun tidak tertulis yang disam- paikan oleh penerima layanan. Selain itu juga hasil rekapan absensi bulanan pegawai menunjukkan tingkat kehadiran pegawai belum optimal dan masih adanya pegawai yang kurang disiplin dalam mentaati jam kerja dalam lingkup Biro Akademik dan Umum Universitas Sulawesi Barat. Hal-hal tersebut menjadi indikasi bahwa kepemimpinan pada unit kerja tersebut belum optimal.

Kepemimpinan sebagaimana dikemukakan oleh Kreither dan Kinichi (Nawawi, 2003:21) adalah upaya mempengaruhi anggota untuk mencapai tujuan organisasi secara sukarela. Pandangan yang sama dikemukakan oleh Gibson (2002) bahwa kepemimpinan adalah menggunakan segala jenis pengaruh yang bukan paksaan untuk memotivasi anggota organisasi agar mencapai tujuan tertentu. Pengertian tersebut menekankan pada kemampuan pemimpin yang tidak memaksa dalam menggerakkan anggota organisasi agar melakukan pekerjaan yang terarah pada tujuan organisasi. Pandangan Katz dan Kahn (Kartono, 2010) menyebutkan bahwa kepemimpinan pada dasarnya dapat diklasifikasikan menjadi tiga kelompok besar yakni sebagai atribut atau kelengkapan dari suatu kedudukan, sebagai karakteristik seseorang, dan sebagai kategori perilaku.

Sejalan dengan hal tersebut analisis kepemimpinan dalam kajian ini diarahkan pada karakteristik kepemimpinan dengan melihat pada aspek karakteristik pribadi pimpinan dengan mengacu pada konsep yang dikemukakan oleh Hersey dan Blanchard (Bennis, 1998). Karakteristik pribadi memiliki peranan yang sangat penting terhadap kepemimpinan seorang pemimpin yang secara langsung memberikan dampak kepada pegawaianya untuk melakukan suatu usaha yang kooperatif dalam mencapai tujuan yang sudah direncanakan. Karakteristik pribadi seorang pemimpin dapat dievaluasi dengan mengkaitkan dengan dimensi meliputi management of attention, management of meaning, management of trust, dan management of self.

\section{Kepemimpinan Transformasional dan Transaksional}

Selama dekade terakhir, universitas telah membuat perubahan mendasar di berbagai bidang seperti pengembangan kurikulum, peran dosen, dan strategi pembelajaran. Perubahanperubahan tersebut telah membawa perubahan 
JIADI: Jurnal Ilmu Administrasi dan Pemerintahan Indonesia Volume 02 No 02 December 2021

Pages 102-110

filosofi yang mendominasi bidang kepemimpinan pendidikan bahwa bentuk kepemimpinan instruksional ini sesuai dengan dunia pendidikan, baik pada tahun 1990-an maupun 2000-an. Namun, perubahan yang dilakukan selama tahun 2000-an tidak dapat diatasi dengan fungsi Pimpinan Universitas sebagai instruksional pemimpin.

Konsep kepemimpinan transformasional secara bertahap mulai menggeser konsep instruksional. kepemimpinan, sebagai harapan dunia pendidikan bagi perguruan tinggi pemimpin untuk membawa tipe kepemimpinan visioner ke dalam organisasi. Amanat yang ditemukan oleh para pemimpin instruksional sulit untuk dipenuhi. pemimpin universitas yang berhasil dalam pekerjaannya telah menggunakan berbagai mekanisme untuk memotivasi dan mengaktifkan staf mereka untuk membawa perubahan dalam budaya universitas mereka. Mengacu kepemimpinan transformasional.

Pengikut dan pemimpin sebagai inspirasi satu sama lain untuk mencapai "tingkat moralitas yang lebih tinggi dan memotivasi keadilan dan kesetaraan. Sedangkan kepemimpinan transaksional mengacu pada pertukaran hubungan antara pemimpin dan pengikutnya. Setiap "membuat kesepakatan" karena harapan untuk bertemu masing-masing kepentingan orang lain dan ini adalah cara pemimpin mempertahankan kinerja dengan memuaskan kebutuhan pengikut.

kepemimpinan transformasional mengikat pemimpin dan pengikut dalam proses kolaboratif dan dengan demikian berkontribusi pada kinerja seluruh organisasi. Kepemimpinan transaksional, sementara itu, tidak mengikat pemimpin dan pengikut dengan cara apa pun kerjasama. Oleh karena itu, tipe kepemimpinan ini menghasilkan lingkungan organisasi yang rutin, tidak kreatif tetapi stabil. Berbeda dengan kepemimpinan transformasional yang membutuhkan sikap responsif dan lingkungan yang inovatif. Persepsi terhadap gaya kepemimpinan ini mengandung penilaian bahwa kepemimpinan transformasional digambarkan lebih bermanfaat daripada kepemimpinan transaksional.

\section{Kepemimpinan Demokrasi}

Pemimpin yang demokratis memberi tahu stafnya tentang segala sesuatu yang memengaruhi pekerjaan mereka dan berbagi pengambilan keputusan dan tanggung jawab peme- cahan masalah.

Pemimpin adalah pelatih yang mendikte tetapi masukan dari staf tidak diabaikan dalam pengambilan keputusan. Ini adalah gaya yang dicirikan dengan produktivitas yang lebih tinggi dan output yang tinggi ini dipertahankan untuk jangka waktu yang lama. Ini karena banyak staf menyukai kepercayaan yang mereka terima dan mendapat respon dari pimpinan dengan kerjasama, semangat tim, dan semangat kerja yang tinggi dalam lingkungan yang demokratis.

Pemimpin demokratis mengembangkan rencana tindakan untuk staf dan memungkinkan mereka untuk menilai aktivitas mereka dibandingkan dengan tujuan yang ditetapkan. Staf dibantu untuk tumbuh hingga batas kemampuan karir mereka. Prestasi juga diakui dan didorong. Gaya kepemimpinan demokratis seperti gaya lainnya memiliki beberapa kelemahan. Ini mungkin yang paling sukses ketika digunakan dengan staf yang sangat terampil atau berpengalaman atau ketika menerapkan perubahan operasional atau memecahkan masalah individu atau kelompok.

Gaya Kepemimpinan menyoroti hal-hal berikut sebagai: kondisi di mana gaya kepemimpinan demokratis dapat digunakan atau tidak digunakan. Bisa jadi paling efektif ketika pemimpin ingin memberi tahu staf tentang hal-hal yang memengaruhi mereka dan pemimpin ingin staf untuk berbagi dalam pengambilan keputusan dan tugas pemecahan masalah. Juga, bisa jadi efektif bila pemimpin ingin memberikan kesempatan kepada staf untuk mengembangkan talent, kepuasan kerja dan untuk mendorong pembangunan tim dan partisipasi. Kepemimpinan Demokratis tidak boleh digunakan ketika tidak ada cukup waktu untuk mendapatkan masukan dari semua orang; hal ini lebih mudah dan lebih hemat biaya bagi manajer untuk membuat keputusan dan bisnis tidak mampu. Kesalahan Para pemimpin demokrasi mendemonstrasikan interaksi manusia untuk memahami.

Kepemimpinan demokratis jika diterapkan dengan integritas, kepemimpinan demokratis dapat mereformasi organisasi yang kaku. Pemimpin yang menggunakan gaya ini menciptakan lingkungan di mana staf diberdayakan untuk memenuhi level tertinggi dari piramida kebutuhan manusai, dan berkembang menjadu anggota masyarakat yang produktif. Pemimpin demokratis adalah pelayan staf dan membimb- 
ing mereka dalam menciptakan dan merangkul visi untuk organisasi. Mereka menginspirasi dan menghasilkan kinerja terbaik dan menciptakan sistem kepercayaan integritas, tujuan di luar diri sendiri, keragaman pemikiran, dan inklusivitas untuk semua ras dan gender Termasuk dalam gaya ini melahirkan kepemimpinan moral, kepemimpinan dengan menyentuh cinta dan kasih sayang kepemimpinan spiritual.

Kepemimpinan moral didasarkan pada martabat dan penghormatan terhadap hak-hak orang lain untuk menentukan nasib sendiri dalam batas-batas moral organisasi. Daripada set yang sewenang-wenang aturan yang harus diikuti, kepemimpinan moral adalah perjanjian untuk melakukan hal yang benar bagi orang lain dan menjalani perjanjian dalam semua interaksi manusia. Juga terkait dengan kepemimpinan demokratis memimpin dengan cinta.

Gaya kepemimpinan ini melampaui memimpin dengan hati, jiwa, dan moralitas dan beralih kekonsep cinta dalam upaya untuk mengedepankan pelajaran dari para pemimpin terdahulu. Kepemimpinan demokratis lebih dikaitkan dengan emosi positif yang dialami oleh staf, sedangkan kepemimpinan otokratis lebih terkait dengan emosi negatif.

Para pemimpin demokratis menginspirasi dan memotivasi staf dengan jelas mengartikulasikan visi yang menjanjikan dan menarik untuk masa depan. Pemimpin demokratis memberikan dukungan kepada staf, mendorong staf untuk belajar dan mengembangkan, dan membangun hubungan baik dengan staf, yang kemudian memupuk persepsi staf yang baik tentang organisasi.

Kepemimpinan otokratis menawarkan penghargaan (atau mengancam hukuman) untuk kinerja perilaku yang diinginkan dan memberikan lebih banyak kontrol. Jenis kepemimpinan ini menghasilkan kepatuhan dan bisa efektif dalam beberapa keadaan, tetapi cenderung tidak menghasilkan kepercayaan dan komitmen untuk bekerja dan evaluasi positif terhadap organisasi.

Kajian ini bertujuan untuk mendeskripsikan karakteristik pribadi pimpinan Kepala Biro Akademik dan Umum Universitas Sulawesi Barat dengan melihat aspek meliputi pengelolaan perhatian, pengelolaan makna, pengelolaan kepercayaan, dan pengelolaan diri.

\section{METODE PENELITIAN}

Penelitian ini dilaksanakan di Universitas Sulawesi Barat dengan lokus penelitian pada kepemimpinan Kepala Biro Akademik dan Umum, fokus penelitian diarahkan pada evaluasi karakteristik pribadi kepemimpinan. Jenis penelitian ini adalah deskriptif kualitatif. Sumber data primer diperoleh melalui observasi langsung yang dimulai pada tahap deskripsi yaitu peneliti memasuki situasi sosial (tempat, aktor, aktivitas), kemudian tahap reduksi menentukan fokus memilih diantara yang telah dideskripsikan. Kemudian tahap seleksi yaitu peneliti mengurai fokus menjadi komponen yang lebih rinci. Data primer juga diperoleh melalui wawancara mendalam (indepth interview) dengan para narasumber atau informan yang ditentukan secara purposive yakni informan yang berinteraksi langsung dengan obyek penelitian terdiri atas pimpinan unit kerja, dosen, dan para pegawai pada Universitas Sulawesi Barat. Data sekunder adalah berbagai data yang sudah tersedia dan diperoleh pada lokasi penelitian. Selain dari data primer dan data sekunder, sumber data juga diperoleh dari literature kepustakaan yang berhubungan dengan masalah penelitian.

Data yang terkumpul dianalisis dengan pendekatan analisis data kualitatif model Miles dan Huberman yakni interaktif model of analysis (Biglen \& Bogdan, 1998). Analisis data dapat digambarkan pada Gambar 1.

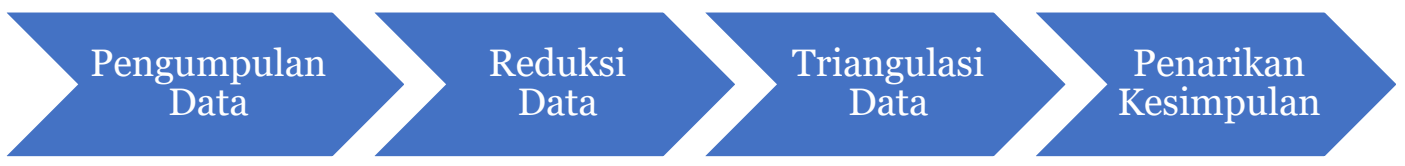

Gambar 1. Model analisis data secara interaktif Sumber: Silalahi, 2009 
J1AD: Jurnal Ilmu Administrasi dan Pemerintahan Indonesia Volume 02 No 02 December 2021 Pages 102-110

Proses analisis data dimulai dari tahap penyediaan data, reduksi atau seleksi data, display atau penyajian data dan pengambilan kesimpulan. Dan proses di atas tidak berjalan secara linear tetapi bersifat simultan atau siklus yang interaktif. Untuk menguji validitas dan realibilitas data dilakukan dengan cara triangulasi yakni triangulasi sumber, teknik dan waktu.

\section{HASIL DAN PEMBAHASAN}

Penelitian yang berlokasi di Universitas Sulawesi Barat dengan mengambil lokus pada unit kerja Biro Akademik dan Umum, yang menjadi lokus penelitian adalah kepemimpinan Kepala Biro Akademik dan Umum. Telaah kajian ini didasarkan pada teori yang dikemukakan oleh Hersey dan Blachard tentang karakteristik pribadi kepemimpinan yang meliputi empat dimensi yaitu management of attention, management of meaning, management of trust, dan management of self. Karakteristik ini dianalisis menggunakan pendekatan kualitatif dengan paparan hasil penelitian secara deskriptif.

Berdirinya Universitas Sulawesi Barat (Unsulbar) sejalan dengan keberadaan Provinsi Sulawesi Barat yang terbentuk pada tanggal 22 September 2004 yang merupakan hasil pemekaran dari Provinsi Sulawesi Selatan. Sejalan dengan itu untuk mendukung provinsi baru maka pada tahun 2007 Unsulbar yang kala itu dikelola oleh Yayasan Pendidikan Indonesia Sulawesi Barat memperoleh izin operasional sebagai perguruan tinggi swasta. Selanjutnya pada tahun 2013, Unsulbar berubah status menjadi perguruan tinggi negeri.

Keberadaaan perguruan tinggi Universitas Sulawesi Barat yang merupakan salah satu Perguruan Tinggi Negeri di Provinsi Sulawesi Barat menjadi tumpuan harapan bagi para pelajar terutama di wilayah Provinsi Sulawesi Barat untuk mengenyam pendidikan tinggi. Universitas Sulawesi Barat memiliki delapan fakultas dan dua puluh empat program Studi. Dalam penyelenggaraan pelayanan kependidikan khususnya pelayanan administrasinya dibawah koordinasi satu Biro yakni Biro Akademik dan Umum. Keberadaan hanya satu biro pada lembaga pendidikan ini membuat unit kerja ini memiliki cakupan kerja yang sangat luas dan menjadi mesin administrasi satu-satunya pada organisasi ini karena menyelenggarakan pelayanan pendidikan, penelitian, dan pengabdian kepada masyarakat. Se- lain itu melaksanakan pelayanan pembinaan minat, bakat, dan kesejahteraan mahasiswa. Dan seluruh pelayanan administratif lainnya pada universitas ini. Oleh sebab itu Kepala Biro Akademik dan Umum ini merupakan jabatan strategis dalam menjalankan roda administrasi perguruan tinggi, sehingga dibutuhkan kepemimpinan yang akomodatif sesuai dengan kebutuhan pimpinan diatasnya dan unit kerja organisasi yang dilayaninya.

Hasil penelitian terhadap dimensi karakteristik pribadi pemimpin dalam hal ini Kepala Biro Akademik dan Umum Universitas Sulawesi Barat dengan merujuk pada empat dimensi karakteristik pribadi pemimpin dari Hersey dan Blanchard (1998) dapat dijabarkan sebagai berikut.

\section{Manajemen of Attention (Pengelolaan Perhatian)}

Pengelolaan perhatian dari seorang pemimpin diharuskan memiliki kemampuan dalam hal memberikan perhatian kepada para pegawainya, sehingga hal tersebut dapat meningkatkan kinerja para pegawai. Perhatian dalam hal ini adalah kemampuan seorang pemimpin untuk dapat mengelola kebutuhan orang yang dipimpinnya. Kebutuhan para pegawai di suatu instansi dapat diketahui apabila seorang pemimpin memiliki kepekaan yang tinggi, sehingga menyebabkan para pegawai merasa mudah untuk menyampaikan baik aspirasi atau masukan dalam rangka untuk meningkatkan kualitas kinerja mereka. Selain itu juga, seorang pemimpin harus memiliki kemampuan yang baik dalam berkomunikasi kepada para pegawainya karena akan berpengaruh terhadap pemberian tugas, wewenang, atau tanggung jawab dengan jelas, sehingga para pegawai atau bawahannya dapat menjalankannya dengan efektif dan efisien.

Hasil penelitian pada karakteristik pemimpin dalam dimensi pengelolaan perhatian menunjukkan bahwa kepemimpinan yang dijalankan oleh Kepala Biro Akademik dan Umum sudah dilaksanakan sebagaimana yang menjadi tugas dan tanggung jawabnya seperti dijelaskan oleh informan 1 (pejabat universitas) dengan menyatakan bahwa: "Kepala Biro selalu memantau kinerja pegawainya dengan terjun langsung ke lapangan sesuai dengan tanggung jawabnya”.

Hal yang sama dikemukakan oleh informan 2 (pejabat universitas) bahwa: "Pak Kepala 
Biro selalu melakukan pegawasan secara menyeluruh kepada seluruh unit memberikan pengaruh yang besar terhadap peningkatan kinerja yang ada di masing masing unit, sehingga secara tidak langsung ketika terjadi penurunan kinerja kepala biro secara langsung memberikan arahan untuk memperbaiki kinerja buruk tersebut".

Penilaian atasan sebagaimana terlihat di atas menunjukkan bahwa Kapala Biro dalam menjalankan tugas sudah sesuai dengan harapan pimpinan, karena bekerja sesuai dengan tugas dan tanggung jawab yang menjadi tugasnya. Sejalan dengan pandangan pimpinan tersebut, berikut dapat dilihat penilaian informan 3 (salah seorang kepala bagian) sebagai berikut: "Demi pengembangan kinerja pegawai Kepala Biro sering mengadakan diskusi dengan para pimpinan unit untuk membicarakan dan sharing pendapat demi mendapatkan solusi pemecahan permasalahan yang efektif dan efisien."

Selain daripada itu perhatian Kepala Biro terhadap setiap masalah yang terkait dengan pekerjaan juga tidak luput dari perhatiannya, sebagaimana dijelaskan oleh Informan 4 (Kasubag Fakultas) sebagai berikut: "Beliau menganggap masalah sekecil apapun harus segera di selesaikan agar tidak terlalu berpengaruh terhadap kinerja pegawai demi menghasilkan hasil yang maksimal."

Berdasarkan hasil wawancara tersebut, terkait dengan kemampuan Kepala Biro Akademik dan Umum Universitas Sulawesi Barat dalam pengelolaan perhatian menunjukkan bahwa kepala biro mampu untuk melakukan penyampaian informasi yang jelas dapat memudahkan proses peningkatan kinerja para pegawai melalui arahan dan masukan. Dengan demikian dapat dikatakan bahwa pengelolaan perhatian yang dilakukan oleh pimpinan (Kepala Biro) karena memiliki kemampuan berkomunikasi yang baik sehingga sangat mendukung dalam proses peningkatan kinerja organisasi.

Pengelolaan perhatian merupakan dimensi penting seorang pemimpin yang memiliki kepedulian terhadap segala hal terkait dengan tugas pokok dan fungsi sesuai dengan kewenangan sebagai pemimpin formal. Perhatian tidak hanya ditujukan kepada tugas-tugas pokok yang dilaksanakan oleh pegawai bawahannya tetapi termasuk juga apa yang diinginkan oleh pimpinan di atasnya. Pengelolaan perhatian dilakukan juga oleh pimpinan dengan melakukan pende- katan pribadi dan komunikasi dengan pegawai, misalnya jika terdapat pegawai yang bermasalah seperti kurang disiplin atau berkinerja rendah, perhatian yang baik dari seorang pimpinan dengan melakukan komunikasi yang baik dapat mengubah perilaku pegawai yang bermasalah.

\section{Management of Meaning (Pengelolaan Makna)}

Karakteristik ini menunjukkan bahwa seorang pemimpin harus memiliki kemampuan dalam melakukan pengelolaan makna yang terkoordinasi dalam proses pemberian pemahaman kepada para pegawai untuk dapat menyelesaikan tugas dan tanggung jawab yang diberikan. Selain itu juga, seorang pemimpin perlu untuk memiliki pengalaman dan pengetahuan dalam melakukan tata kelola organisasi yang baik dan dapat memberikan dampak positif peningkatan kinerja para pegawainya.

Seorang pemimpin diharapkan memiliki kreativitas yang tinggi dalam beinteraksi dengan para pegawai atau bawahannya. Sebagai seorang pemimpin, mereka dituntut untuk memiliki kemampuan dalam membuat kombinasi baru, berdasarkan data, informasi, atau unsur-unur yang sudah ada atau dikenal sebelumnya, yaitu semua pengalaman dan pengetahuan dalam melakukan tata kelola organisasi yang baik. Sehingga, dapat memberikan dampak yang baik kepada para pegawai atau bawahannya agar dapat meningkatkan kinerja pegawai tersebut dalam mengemban tugas, wewenang, serta tanggung jawabnya. Dari hasil penelitian menunjukkan penilaian informan mengenai pengelolaan makna oleh pimpinan dijelaskan oleh salah seorang Informan 5 (Kepala Bagian) sebagai berikut: "Sejatinya Kepala Biro perlu untuk memikirkan beberapa program kegiatan yang mendukung untuk meningkatkan kinerja pegawai. Apakah dalam bentuk keikutsertaan pegawai dalam kegiatan pelatihan atau sosialisasi”.

Pendapat yang sama dijelaskan oleh Informan 6 (Staf) mengenai pengelolaan makna oleh pimpinan, dijelaskan sebagai berikut: "Kegiatan peningkatan kapasitas bagi para pegawai masih sangat kurang, khususnya bagi kami di bagian SDM. Sangat penting untuk kami bisa mengikuti kegiatan untuk meningkatkan pengetahuan kami agar lebih terupdate".

Pendapat yang sama dikemukakan oleh salah seorang staf pada fakultas (Informan 7) di- 
JIADI: Jurnal Ilmu Administrasi dan Pemerintahan Indonesia Volume 02 No 02 December 2021

Pages 102-110

jelaskan sebagai berikut: "Sampai hari ini mungkin kegiatan seminar, pelatihan, atau sosialisasi masih sangat kurang untuk kita ikuti/hadiri karena dari pihak pimpinan masih membatasi padahal sangat penting”.

Berdasarkan hasil wawancara dari beberapa informan di atas menunjukkan bahwa pengelolaan makna oleh pimpinan khususnya terkait dengan kepentingan bawahan yang dipimpinnya memperlihatkan kondisi yang masih rendah, sehingga hal ini belum dirasakan oleh para bawahan terkait dengan pengembangan sumber daya manusia khususnya para pegawai level staf. Dengan kondisi seperti ini, maka Kepala Biro Akademik dan Umum Universitas Sulawesi Barat perlu untuk mempertimbangkan adanya beberapa penyediaan kegiatan untuk menunjang peningkatan kinerja para pegawai. Kreativitas dan inovasi merupakan kemampuan untuk menerapkan solusi kreatif terhadap masalah dan peluang untuk meningkatkan atau untuk memperkaya kehidupan orang-orang. Inovasi sebagai suatu gagasan baru yang diterapkan untuk memprakarsai atau memperbaiki suatu produk atau proses dan jasa.

\section{Management of Trust (Pengelolaan Ke- percayaan)}

Karakteristik pribadi pemimpin yang tidak kalah pentingnya adalah pengelolaan kepercayaan, hal ini berarti seorang pemimpin harus memiliki kemampuan untuk dapat dipercaya oleh para pegawainya. Selain itu juga, seorang pempimpin harus memiliki kemampuan untuk dapat menjalankan roda organisasi pemerintahan secara tepat dan konsisten. Keandalan dapat mencapai tujuan suatu organisasi dengan benar sampai kurun waktu tertentu. Pemenuhan terhadap pencapaian tujuan organisasi yang tepat dan memuaskan meliputi ketepatan waktu dan tidak mengecewakan kepada para pegawainya.

Dimensi pribadi karakteristik kepemimpinan dalam hal pengelolaan kepercayaan seoramg pemimpin dimaknai bahwa seorang pemimpin harus memiliki kemampuan untuk dipercaya dan bersifat konsisten. Seorang pemimpin diharuskan dapat memiliki kemampuan untuk memberikan pelayanan yang baik serta menjanjikan kepada para pegawai atau bawahannya. Selain itu juga, seorang pempimpin diharuskan untuk memiliki kemampuan barupa keandalan untuk menjalankan roda organisasi secara tepat dan konsisten. Keandalan dapat mencapai tujuan suatu organisasi dengan benar sampai kurun waktu tertentu. Pemenuhan terhadap pencapaian tujuan organisasi yang tepat dan memuaskan meliputi ketepatan waktu dan tidak mengecewakan kepada para pegawai atau bawahannya.

Pandangan informan mengenai dimensi karakteristik kepemimpinan Kepala Biro Akademik dan Umum terkait dengan aspek pengelolaan kepercayaan dapat dilihat penilaian informan 8 (Kepala Bagian) sebagai berikut bahwa "Kepala Biro perlu untuk memberikan contoh kedisiplinan kepada para pegawainya agar dapat dijadikan panutan". Kedisiplinan yang dicontohkan oleh pemimpin dapat menjadi bentuk mengelola kepercayaan yang ditampilkan oleh pimpinan, kedisiplinan yang konsisten ditampilkan oleh pimpinan memberikan efek percaya dari semua bawahan bahwa pimpinan dapat diteladani sebagai pimpinan maupun sebagai pribadi.

Hasil wawancara salah seorang informan 9 (Staf) juga memberikan informasi mengenai management of trust yang menjadi karakteristik pribadi pemimpin dijelaskan sebagai berikut: "Saya menyadari bahwa untuk beberapa permasalahan kadang proses penyelesaiannya membutuhkan waktu yang relatif lebih lama, sehingga harus membutuhkan penyesuaian”.

Pandangan informan di atas memberikan informasi bahwa setiap permasalahan yang terjadi terkait dengan pelaksanaan tugas pokok dan fungsi yang menjadi kewenangan Kepala Biro dapat diselesaikan sekalipun kadangkala membutuhkan waktu. Hal ini terjadi karena adanya prinsip kehati-hatian yang dijalankan oleh Kepala Biro dalam menjalankan tugasnya. Penyelesaian masalah terkait pekerjaan apabila terlaksana dengan baik maka akan memberikan kepercayaan yang tinggi kepada pimpinan bahwa pimpinan dapat memberikan solusi terbaik dalam mengatasi masalah pekerjaan yang ada. Sekalipun demikian pandangan informan lain (Informan 10 Kasubag) "menyatakan bahwa belum maksimalnya penerapan konsistensi dan ketepatan waktu dalam menjalankan serta melaksanakan tugas dan tanggung jawab Kepala Biro", sehingga hal ini dipandang sebagai hal yang kurang optimal dalam aspek pengelolaan kepercayaan yang minim.

\section{Management of Self (Pengelolaan Diri)}

Dimensi karakteristik pribadi pemimpin dalam hal pengelolaan diri menunjukkan kema- 
tangan seorang pemimpin dalam menjalankan kepemimpinannya. Seorang pemimpin diharuskan memiliki kemampuan dalam mengendalikan emosi personal. Kemampuan dalam mengendalikan diri akan memberikan pengaruh positif terhadap kecerdasan emosional seorang pemimpin. Seorang pemimpin perlu memiliki kemampuan dalam memahami dan mengenali dirinya sendiri sebagai seseorang yang memiliki peranan penting di sebuah organisasi untuk menggerakkan para pegawainya dalam mengarahkan suatu organisasi ke arah yang positif.

Pengelolaan diri menjadi aspek penting yang menjadi karakteristik pribadi seorang pemimpin yang secara khas dimiliki oleh setiap pemimpin, dan tidak dimiliki oleh pemimpin lainnya. Seorang pemimpin diharuskan memiliki kemampuan mengendalikan diri dalam batas kekuatan dan kelemahan yang dimiliki. Kemampuan dalam mengendalikan diri adalah pondasi paling besar seorang pemimpin yang membangun seluruh kecerdasan emosional.

Hasil wawancara yang dilakukan terhadap beberapa informan terkait dengan pengelolaan diri pimpinan terlihat dari pandangan Informan 11 yang mengemukakan pandangannya sebagai berikut: "Pak Kepala Biro memiliki kepribadian yang sangat tenang dan bijaksana, karena setiap kali ada permasalahan Kepala Biro melakukan analisis secara menyeluruh terhadap akar permasalahan dan mencari solusi terhadap permasalahan dengan berdiskusi dengan beberapa kepala unit kerja dalam ruang lingkup Universitas Sulawesi Barat.”

Informasi lain yang diperoleh dari Informan 11 mengenai pengelolaan diri Kepala Biro dijelaskan sebagai berikut: "Kepala Biro Akademik dan Umum Universitas Sulawesi Barat sangat rendah hati sehingga mau mendengar semua keluhan dan pendapat dari siapapun”. Berdasarkan hasil wawancara tersebut menunjukkan bahwa pengelolaan kepribadian Kepala Biro memiliki komitmen untuk tidak berlaku diskriminasi terhadap siapapun. Pandangan dari informan lainnya terhadap kemampuan pengelolaan kepribadian Kepala Biro juga dikemukakan oleh salah seorang informan Kepala Sub Bagian (Informan 12) bahwa "Kepribadian Kepala Biro cukup santun dalam menyampaikan teguran terutama kepada pegawai yang memiliki pelanggaran begitu juga terhadap pegawai yang berprestasi, Kepala Biro selalu memberikan pujian dan penghargaan".

Sejalan dengan informasi dari beberapa informan terkait dengan kemampuan pengelolaan diri hal itu menunjukkan bahwa Kepala Biro memiliki kecerdasan emosional sebab mampu merefresentasikan dirinya sebagai wakil daripada organisasi. Sehingga citra organisasi menjadi baik. Kecerdasan emosional yang ditampilkan oleh pimpinan menunjukkan kemampuannya dalam mengelola diri, yakni apa yang pantas dan tidak pantas dilakukan. Tugas utama pemimpin adalah membangkitkan semangat kerja dan menginspirasi bawahannya melalui keteladanan yang ditampilkan supaya kinerja pegawai menjadi lebih baik dan kinerja organisasi secara keseluruhan lebih meningkat.

\section{SIMPULAN DAN SARAN}

\section{Kesimpulan}

Berdasarkan paparan hasil kajian mengenai dimensi karakteristik pribadi pimpinan Kepala Biro Akademik dan Umum di Universitas Sulawesi Barat terlihat bahwa dari empat dimensi sesuai dengan pendapat Hersey dan Blanchard mengenai karakteristik pribadi pemimpin yang meliputi karakteristik management of attention, karakteristik management of self telah berjalan dengan maksimal. Namun pada dimensi management of meaning belum berjalan dengan maksimal disebabkan oleh kemampuan Kepala Biro Akademik dan Umum Universitas Sulawesi Barat dalam mengaplikasikan kreativitasnya kepada para pegawai atau stafnya dianggap belum berjalan dengan optimal seperti berupaya untuk menyediakan beberapa kegiatan-kegiatan pendukung kepada para pegawai untuk meningkatkan kemampuan mereka di setiap bidang. Demikian juga pada dimensi karakteristik management of trust belum optimal disebabkan oleh belum maksimalnya penerapan konsistensi dan ketepatan waktu dalam menjalankan serta melaksanakan tugas dan tanggung jawabnya.

\section{Saran}

Sejalan dengan hasil penelitian sebagaimana disimpulkan di atas, maka beberapa hal yang dapat disarankan terkait dengan optimalisasi penguatan karakteristik pribadi pemimpin dalam hal ini Kepala Biro Akademik dan Umum Universitas Sulawesi Barat yang dapat meningkatkan kinerja pegawai yang dipimpinnya ada- 
JIADI: Jurnal Ilmu Administrasi dan Pemerintahan Indonesia Volume 02 No 02 December 2021 Pages 102-110

lah perlu meningkatkan kreativitas dan konsistensi terkait dengan karakteristik pengelolaan perhatian (management of attention) terutama yang berhubungan dengan perhatian terhadap masalah-masalah pekerjaan, melakukan komunikasi secara intensif terhadap pegawai yang dinilai kurang disiplin. Kemudian perlu penguatan pada karakteristik pengelolaan makna (management of meaning) khususnya terkait dengan penyediaan fasilitas kepada pegawai dalam rangka pengembangan diri yang dapat menunjang peningkatan kinerjanya.

\section{DAFTAR PUSTAKA}

Gibson. 2002 . Organisasi Perilaku-struktur proses terjemahan, Edisi V. Jakarta: Penerbit Erlangga.
Hersey, Paul dan Blanchard, Kenneth.1998. Manajemen Perilaku Organisasi: Pendayagunaan Sumber Daya Manusia. Edisi Keempat: Penerbit Erlangga

Kartono, Kartini. 2010. Pemimpin dan Kepemimpinan. Jakarta: Raja Grafindo Perkasa.

Keban, Yeremias T. 2004. Enam Dimensi Strategis Administrasi Publik, Konsep,. Teori dan Isu. Yogyakarta: Gava Media.

Miles, B. Mathew dan Michael Huberman. 1992. Analisis Data Kualitatif Buku Sumber Tentang Metodemetode Baru. Jakarta: UIP.

Nawawi, Hadari. 2003. Manajemen Sumber Daya Manusia Untuk Bisnis yang. Komptitif. Gadjah Mada University Press: Yogyakarta.

Silalahi, Ulber. 2009. Metode Penelitian Sosial. Bandung : Refika Aditama.

Yukl, Garry. 1998. Kepemimpinan dalam Organisasi. Jakarta: Prenhallindo. 